\title{
PENAHANAN DAN PENANGGUHAN PENAHANAN DALAM TEORI DAN PRAKTEK
}

\author{
Thomas Abbon \\ Thomas.abbon@gmail.com \\ Universitas Kristen Indonesia, Jakarta, Indonesia
}

\begin{abstract}
The issue of upholding the rule of law is a chore that must be resolved by the current government. The state and nation have been disadvantaged from all aspects, because in the end the harassment of the law has given rise to corruption, collusion and nepotism. One of the things that stands out about law enforcement is the issue of detention and suspension of detention and sentencing that has to do with detention. The problem of detention and the detention in practice so far has been widely distorted by unscrupulous law enforcers and this institution has become an "open business arena". Detention and suspension of detention is actually a legal effort, which aims to realize the enforcement of the law itself, because detention is only allowed as long as there is suf cient preliminary evidence, and detention is solely in order to facilitate investigation / examination and besides that detention is also intended as protecting the suspect / defendant from violence / other people (eigenrichting). The suspension of detention should be able to be given to every suspect / defendant who provides guarantees according to the law, unless otherwise speci ed in certain cases. In addition there is another side of the Criminal Procedure Code which determines that detention is part of punishment, so it has become a habit in practice that if a suspect I defendant who was originally detained "must be sentenced". From the facts that are decomposed in the past this has brought a a very dif cult situation to nd out who really deserves detention or suspended detention and it turns out everyone is nally able to pay "anything" to release himself from the snare of detention even though it should not be his right.
\end{abstract}

Keywords: rule of law; corruption, collusion, and nepotism; legal effort.

\section{Pendahuluan}

Proses Peradilan Pidana (Criminal Process) terhadap Tersangka Pelaku tindak pidana dimulai pada tahap Pra Adjudikasi ditingkat Kepolisian, Kejaksaan dan Adjusikasi di Pengadilan serta Post Adjudikasi. Penahanan yang diatur oleh UndangUndang No. 8 tahun 1981 tentang KUHAP dikenal penahanan rumah, penahanan kotaserta penahanan rumah tahanan negara, (pasal 22). Penahanan itu sendiri dapat dilakukan oleh Polisi sebagai penyidik; Jaksa sebagai Penuntut Umum; serta Hakim.

Keperluan penahanan untuk kepentingan pemeriksaan adalah mencegah Tersangka agar tidak melarikan diri, tidak menghilangkan barang bukti dan agar Tersangka tidak mengulangi tindak pidana.
Adanya Lembaga Penahanan yang diatur undang-undang sekaligus memberikan diskresi (discretionary of power) kepada ketiga sub sistem pengadilan pidana. Masalah yang timbul dari adanya Lembaga Penahanan didalam praktek, betapa seringnya lembaga ini "diperdagangkan" oleh ketiga subsistem dengan mengeksploitasi kecemasan Tersangka atau keluarganya karena kebebasan dan kemerdekaannya dirampas atau sebaliknya ketiga sub sistem ini dimanfaatkan oleh kepentingan oknum-oknum tertentu dengan tujuan untuk mendapatkan keuntungan materi.

Tulisan ini bertujuan agar Lembaga Penahanan dapat mewujudkan suatu Proses Hukum yang adil (Due Process of Law) demi tercapainya suatu penegakan hukum (Law Enforcement). 


\section{Pembahasan}

\section{Sistem Peradilan Pidana}

Sistem Peradilan Pidana adalah suatu pengertian untuk memahami bekerjanya Hukum Pidana di masyarakat serta bagaimana Hakim menerapkannya. Sistem Peradilan Pidana mulai bekerja pada saat adanya laporan kejahatan dari masyarakat ke Kepolisian, dalam hal ini Polisi melakukan penyelidikan/penyidikan. Bila ada bukti permulaan yang cukup, maka Polisi dapat melakukan upaya paksa baik itu penangkapan ataupun penahanan. Selanjutnya, bilamana pemeriksaan oleh Penyidik dianggap telah cukup, maka berkas perkara berikut tersangkanya dilimpahkan ke Kejaksaan. Kemudian Kejaksaan akan meneliti Berkas Perkaranya, bila memenuhi persyaratan, Jaksa yang ditunjuk, sebagai penuntut umum akan membuat surat dakwaan yang selanjutnya diteruskan kepada Hakim untuk diperiksa dan diadili Dalam pada itu Hakim pun akan meneliti surat dakwaan, bila dakwaan tidak tepat/tidak memenuhi syarat, Hakim dapat menolak dakwaan, sebaliknya bila semuanya sudah memenuhi persyaratan maka Hakim akan memeriksa dan memvonis bersalah tidaknya terdakwa. Bila bersalah, ia akan menjalani pidana penjara di Lembaga Pemasyarakatan.

\section{Lembaga Penahanan}

Lembaga Penahanan sebagaimana telah diatur dalam KUHAP, sesungguhnya merupakan salah satu alat penegakan hukum (law enforcement), sebab dengan diadakan penahanan terhadap seseorang tersangka/terdakwa diharapkan pemeriksaan atas dirinya dapat berjalan lancar, karena dengan penahanan itu seorang tersangka/terdakwa akan lebih mudah diperiksa bila sewaktu-waktu diperlukan, serta sangat kecil kemungkinan barang-barang bukti yang berkaitan dengan kejahatan yang dilakukannya itu dimusnahkan. Dilain pihak dalam kasus-kasus pidana tertentu, penahanan terhadap si tersangka/terdakwa bertujuan melindungi dirinya dari tindakan Eigenrichting main hakim sendiri) dari pihak lain.

Akan tetapi konstruksi penahanan yang diatur di dalam pasal 24 s/d 28 JU No. Tahun 1981 tentang KUHAP didalam prakttek selalu menimbulkan "masalah", khususnya bila tersangka dikenakan penahanan dalam rumah tahanan negara. Waktu penahanan sebanyak 400 hari untuk seluruh proses peradilan pidana, sangat mungkin "diperdagangkan" baik oleh Polisi sebagai penyidik, Jaksa sebagai Penuntut Umum maupun Hakim serta Penasehat Hukum ataupun oleh pelapor sendiri. Kewenangan yang diberikan Undang-Undang ini didukung dengan adanya penangguhan penahanan sebagaimana diatur oleh pasal 61 KUHAP, yang menyatakan atas permintaan tersangka atau terdakwa atau penasehat hukumnya dapat dilakukan penangguhan penahanan atas diri tersangka/terdakwa dengan atau tanpa jaminan uang atau jaminan orang.

Kewenangan yang diberikan oleh UndangUndang ditambah dengan kecemasan tersangka/ terdakwa atau keluarganya dapat menjadikan proses peradilan pidana tidak menggambarkan proses hukum yang adil. Kecemasan atau ketakutan tadi dapat menjadi pendorong utama Tersangka/Terdakwa atau penasehat Hukumnya untuk berani melakukan tindakan yang bertentangan dengan hukum. "Kehilangan Kemerdekaan" yang mengakibatkan tersangka/Terdakwa tidak dapat berkomunikasi dan berhubungan dengan lingkungan sosial masyarakat, terhambatnya usahabisnis, maupun ketakutan akan perlakuan sesama tahanan memperbesar kemungkinan untuk mengusahakan dengan jalan "menyuap" aparat penegak hukum agar ditangguhkan penahanannya. Aparat penegak hukumpun pasti terlindung dibalik asal 31 Undang-Undang No. 8 Tahun 1981. Dalam hal ini yang mengalami kerugian selalu tersangka/ terdakwa dan tidak sedikit biaya yang harus dikeluarkan, disamping itu saksi korban maupun keluarganya tidak dapat bertindak. Adanya wewenang yang diberikan oleh Undang-Undang pada Polisi, Jaksa serta Hakim sulit bisa kita menerima proses peradilan itu berjalan dengan ajar begitu juga terhadap putusannya-pun sering menderitakan pencari keadilan an kewibawaan hukum itu sendiri.

Memang disadari bahwa pada akhirnya ketentuan-ketentuan tentang Lembaga Penahanan yang diatur didalam KUHAP, dapat tidaknya berjalan sungguh-sungguh, terpulang kepada karakter ok- 
num Penegak Hukum. Sebab pengertian tentang "adanya bukti permulaan yang cukup, kepentingan penyelidikan/penyidikan atau tidak melarikan diri, tidak menghilangkan bukti dan tidak mengulangi tindak pidana" yang dipakai sebagai dasar penahanan, penangguhan penahanan atau pencabutan penangguhan penahanan lebih banyak dipengaruhi faktor subjektif dari pelaksanaan oknum Penegak Hukum tersebut.

Didalam praktek ada kalanya seseorang yang belum memiliki bukti permulaan yang cukup untuk disangka melakukan tindak pidana telah dilakukan penahanan dan ada kalanya oknum Penegak Hukum dengan menyatakan demi kepentingan penyidikan, penuntutan, pemeriksaan ataupun agar si tersangka/terdakwa tidak melarikan diri, tidak menghilangkan barang bukti atau tidak mengulangi tindak pidana dilakukan penahanan. Akan tetapi dilain pihak tidak jarang pula seseorang tersangka/terdakwa yang telahditahan berdasarkan bukti permulaan yang cukup, sedemikian mudahnya ditangguhkan penahanan atas dirinya, atau balikan dalam banyak kasus pidana, seseorang yang menurut bukti-bukti sudah cukup untuk ditahan, tidak ditahan.

Mengenai hal itu, Kapolri dalam Surat Keputusannya No. Pol. SKEEP/04/1/1982, tanggal 18 Pebruari 1982 menentukan, bahwa bukti permulaan yang cukup itu, adalah bukti yang merupakan keterangan dan data yang terkandung didalam dua di antara :

- Laporan Polisi;

- Berita Acara Pemeriksaan di TKP;

- Laporan Hasil Penyelidikan;

- Keterangan Saksi/Saksi Ahli; dan

- Barang Bukti.

- Yang setelah disimpulkan menunjukkan telah terjadi tindak pidana kejahatan.

P.A.F. Lamintang, dalam bukunya Kitab Undang-Undang Hukum Acara Pidana, mengatakan bahwa "bukti permulaan yang cukup" dalam rumusan pasal 17 KUHAP itu harus diartikan sebagai "bukti-bukti minimal", berupa alat- alat bukti seperti dimaksud dalam pasal 184 (1)
KUHAP, yang dapat menjamin bahwa Penyidik tidak akan menjadi terpaksa untuk menghentikan penyidikannya terhadap seseorang yang disangka melakukan tindak pidana setelah terhadap orang tersebut dilakukan penangkapan.

Rapat kerja Mahkamah Agung, Kehakiman, Kejaksaan, Polisi atau MAKEHJAPOLI, tanggal 21 Maret 1984 menyimpulkan, bahwa bukti permulaan yang seyogyanya minimal : Laporan Polisi ditambah salah satu alat bukti lainnya.

Pengadilan Negeri Sidikalang-Sumatera Utara, melalui penetapannya No. 4/Pred-Sdk/ 1982, tanggal 14 Desember 1982 menentukan :

1. bahwa Penyidik berwenang untuk melakukan penangkapan dan penahanan sejauh tindakan itu dilakukan dalam batas-batas ketentuan pasal 17 dan 21 (1) KUHAP, yaitu penangkapan berdasarkan bukti cukup dan tentu saja bukti permulaan yang cukup dan bukti yang cukup tersebut ada terlebih dahulu sebelum diadakannya penangkapan dan atau penahanan;

2. bahwa bukti permulaan yang cukup dan bukti yang cukup dikemukakan di atas kiranya tidak merupakan dan tidak termasuk salah satu alat bukti yang disebutkan dalam pasal 184 KUHAP, dan menurut Pengadilan Negeri hal tersebut sebagai bukti lebih merupakan informasi untuk mengusut daripada sebagai alat bukti yang memberikan dugaan keras, bahwa pemohon telah melakukan tindak pidana perkosaan dan pembunuhan Rbp;

3. Penangkapan dan penahanan atas diri pemohon adalah tanpa alasan yang berdasarkan Undang-Undang.

Sedangkan Luhurt M P Pangaribuan, mengatakan penahanan terhadap seseorang harus memenuhi dua syarat yakni juridis dan nesesitas (necessity). Syarat juridis menyangkut ancaman hukuman 5 tahun keatas dan syarat nesesitas berkaitan dengan apakah yang bersangkutan dianggap perlu ditahan karena dikhawatirkan bisa menghilangkan barang bukti dan menghambat proses pemeriksaan. Oleh karena itu pada syarat nesesitas sangat perlu diperhatikan dan diper- 
timbangkan tentang untung ruginya menahan seseorang akan kenyataan-kenyataan daripada aktivitas tersangka. Artinya bilamana tersangka adalah orang yang sedang menjalankan tugas untuk kepentingan orang banyak (mis : Pimpi- nan Perusahaan, Pejabat), perlu atau tidak untuk ditahan.

Selain daripada itu pasal 22 ayat (4) KUHAP dinyatakan masa penangkapan dan atau penah- anan dikurangkan seluruhnya dari pidana yang dijatuhkan. Ketentuan pasal ini memberi makna bahwa seseorang yang ditahan adalah sama den- gan dipidana. Oleh karena itu pasal ini sesung- guhnya telah menimbulkan kontradiksi dengan asas praduga tak bersalah dan dengan adanya pasal tersebut pula sering dipakai sebagai alasan pembenaran yang sama bagi penegak Hukum, khususnya Hakim dalam menjatuhkan putusan- nya, dimana bila dalam suatu perkara tersebut tersangka/terdakwanya ditahan. Itu berarti harus dijatuhkan hukuman (bersalah). Aturan seperti ini sudah pasti tidak benar dalam mengejar Penega- kan Hukum yang adil.

\section{Kesimpulan dan Saran}

Sebagai suatu Negara, yang mengakui Hukum men- jadi pengatur perilaku aparat dan warganya maka Hukum sudah seharusnya menjadi harapan pencari keadilan. Sebagai suatu lembaga yang sesuai diakui dalamproses peradilanpidana, penahanan hendaknya tidak disamakan dengan hukuman. Adanya istilah potong masa tahanan dengan hukuman yang dijatuhkan, bukanlah berarti mengalami masa tahanan sama dengan mengalami masa hukuman.

Begitu pula halnya dengan penahanan atau penang- guhan penahanan. Sudah sepatutnya tidak dipergunakan sebagai komoditi yang dapat dibeli. Kecemasan serta ketakutan Tersangka/Terdakwa akan penahanan sehar- usnya dilindungi. Hal ini untuk mendukung lembaga penahanan yang kegunaannya untuk mempercepat proses peradilan pidana yang cepat serta biaya ringan dapat terwujud dengan baik. 


\section{Daftar Pustaka}

Abdul Hakim Garuda Nusantara, Luhut Pan- garibuan, Mas Ahmad Santosa, KUHAP dan Peraturan-Peraturan Pelaksana, Djambatan, Jakarta, 1996.

Darwan Prints, Hukum Acara Suatu Pengantar,

Djambatan, Jakarta, 1989.

Djoko Prakoso, Surut Dakwaan. Tuntutan Pidana dan Eksaminasi Dalam Perkara Didalam Proses

Pidana, Liberty, Yogyakarta, 1988.

Erni Widhayanti, Hak-Hak Tersangka/Terdakwa Dalam KUHAP, Liberty, Yogyakarta, 1988.

Kitab Undang-Undang Hukum Acara Pidana (KUHAP).

R. Susilo, KUHP, Poletia, Bogor, 1983.

Pembahasan Hukum Acara Pidana dalam Teori dan Praktek.

Nawawi Arief, Barda, Perbandingan Hukum Pidana,

Raja Grafindo Persada, Jakarta, 1994.

Sianturi, SH, Hukum Pidana Khusus, Diklat, AHM- PTHM, Jakarta, 1994.

Sudarto, Hukum dan Hukum Pidana, Alumni, Band- ung, 1983. 